\title{
ALLOMORPHIC FEATURES OF STYLISTICALLY MARKED INVERTED SYNTACTIC MODELS (WITH REFERENCE TO ENGLISH AND UKRAINIAN FICTION TEXTS)
}

\author{
Orest Tolochko \\ Lecturer, Ivan Franko National University of Lviv, Ukraine \\ e-mail: tolor@ukr.net,orcid.org/0000-0003-4349-5392
}

\section{Summary}

The article elucidates allomorphic syntactic models with inversion in English and Ukrainian, as Indo-European languages of different groups. The key emphasis is put on the expressive potential of these syntactic structures, while taking into account their frequency and distributional behavior as well. The latter show direct dependence of inverted constructions stylistic connotation upon the word order patterns of a specific language and determine an extent of expressive colouring of particular cases of inversion. The allomorpism of this linguistic category in English and Ukrainian manifests itself in syntactic models. The latter acquire a special status in English due to the limitation of their usage in fiction texts. This feature is not typical of the Ukrainian Language. The constructions with an introductory there, emphatic do and a prepositional position constitute distinctive English structures; the syntactic models with existential and movement semantics display allomorphic parameters typical of Ukrainian. The two languages text systems, though, require complex consideration from the point of view of different language levels in the micro- and macrocontextual framework as a key factor complementing the discourse expressiveness.

Keywords: inversion, allomorphic syntactic models, expressiveness, contextual factor, languages of distant genetic relationship, connotation.

\section{DOI: https://doi.org/10.23856/4207}

\section{Introduction}

The contrastive study of stylistic categories in distantly related cognate Indo-European languages, such as Ukrainian and English, remains topical in contemporary linguistics. The article's aim is the study of allomorphic inverted expressive models in the original fiction texts of the languages of distant genetic relationship. The research object includes fiction contexts containing allomorphic inverted syntactic structures in English and Ukrainian. The research $s u b$ ject is focused on consideration of allomorphic inverted syntactic models and their expressive features in the Indo-European languages of different groups.

The empirical data for the research were collected from English and Ukrainian XX century prose fiction - "Sons and Lovers" by D. H. Lawrence and "Chotyry brody" (Four Fords) by M. Stelmakh. The selected works provide true-to-life depiction of common people (minors and peasants) life, their characters and images as typical representatives of their epoch with their lives affected by political, economic, social, and cultural environment.

Inversion as a stylistic category has not been confined to pure shifting of sentence components to "a logically stressed position" but also it serves as a means of increasing a statement's pragmatic value in the process of text formation, with a view to influence the cognitive activity of a recipient (Kochetova, 2014). 
The English contexts containing inverted structures with the use of auxiliary or modal verbs are not devoid of stylistic connotation. Modality is viewed by linguists as a statement's expression of real or unreal character in its relation to an object of thought (Galperin, 2006).

\section{Allomorphic features of stylistic inversion: theoretical domain}

With that in view the following features should be considered: (a) isomorphism of the basic syntactic models; (b) expansion of these syntactic structures; (c) interdependence of the inverted constructions frequency and structural schemes; (d) fixed or non-fixed order of elements position within the syntactic model with an account of the units relation within the structure; (e) determination of compulsory and arbitrary units hierarchy within a certain language system. The lingual divergences specify (1) the number of syntactic models options; (2) a unit relevant or irrelevant syntactic position between the subject and person-marked verbal element; (3) the number of expedient inverted elements usage in English and Ukrainian syntactic systems (Obraztsova 2011: 12-13). The above mentioned testifies to more evident functional stipulation of "the linear expansion principle" in the English sentence with word order determining its structure and syntactic type. The character of syntactic unit expansion within the Ukrainian clause is devoid of such primary significance. The English syntactic element position in relation to its immediate surrounding constitutes a crucial parameter defining its syntactic links within the sentence as a structural unit. The specificity of the contrasted languages syntactic systems is as well predetermined by unequal syntactic links relevance among the construction elements. The opposition of the so-called "fixed" English and "relatively free" Ukrainian word order is relevant as word order in Slavonic languages is being restrained by a numerous factors. Relative variety of them decreases its functional potential. The tentative variety of word order models cannot be regarded universal. Thus, a particular syntactic model may require a certain grammatical expression and be deemed relevant in a specific communicative situation largely determined by functional sentence perspective. The latter is conditioned by the sentence logical scheme. The sentence is predominantly influenced by the contextual factor. Thus, the sentence is considered a key autonomous means of the fact-forming information expression to an extent it coincides with a statement. In this relation each type of syntactic construction semantics requires interaction with other semantic type structures especially those attaching predicates (Atutyunova, 1999). The sentence semantic structure may be shaped to designate its factual information. The topicalization of the latter may be achieved by a unit or prepositional element constituting a predicates source inversion that reflects the unit semantics or prepositional relations thus transferring a statements load centre to denote an attitude to the depicted reality (Arutyunova, 1999: 408). K. Fiala argues that a sentence prepositional statement parts correlate to display syntactic completion. Ending one statement and starting the following a speaker may choose to shape its expansion. The succeeding construction is generally identical to the preceding one (Fiala, 1995). To corroborate the mentioned A. Pavlova states that the unit's semantics reveals their dynamic character. The latter involves a kind of the expected information expansion by a recipient putting an emphasis (Pavlova, 2009: 89) The Polish linguist I. Kałuża related the researched problem to the so called "deviant sentences. These sentences, presumably, should not upset the language principles and be subject to semantic interpretation (Katuza, 1975: 93-103). V. Yartseva confirms close ties of the language lexical and grammatical levels. The research comprehensiveness and objectivity can be achieved when taking into account all the units relations within the language system. 
The contrastive analysis of language items involves indication of isomorphic features as opposed to their allomorphic characteristics (Yartseva, 1980).

Having considered the sentence typology in the languages of distant relationship, V. Arakin developed the criteria of the narrative sentence types classification: (1) sentence structure (one member / two member); (2) syntactic predicate position (initial / middle / end); (3) subject-predicate relations (coordinated / non-coordinated); (4) attribute preposition / postposition; (5) fixed / non-fixed word order. The enumerated parameters form a stable feature cluster to designate a sentence as a basis for the contrastive analysis. The word order (with an inversion as its specific type) forms an essential category in the language binary contrasting (Arakin, 1995: 176). The unequal expressive potential of inverted syntactic models in English and Ukrainian has been largely predetermined by their structural divergences.

The verbalized reveal the communicant world picture. Expressive communication reflects the speaker's pragmatic intention. The latter can find its vivid manifestation in fiction as the writer consciously selects definite stylistic elements (inverted models in particular) taken from a variety of means relating to different language levels to shape a certain text perception on the part of a recipient (Shakhovskiy, 2008: 133-134). It includes the notion of a "marked element" presupposing an indication of some specific features a lingual category possesses as well its frequency and distributional behavior. The latter indicates usage contexts of this category. The typological study of a lingual category includes its usage, semantic and pragmatic structure, and morphological and semantic construction features relevant to the situation, as well the interdependences among the situation components, as well as other linguistic means, in particular structural factors and external (additional) factors attached to that category (Croft, 1993: 70). When considering contrastive analysis parameters the micro- and macrocontextual levels should be singled out. The first one is related to a certain language items contrast; the second one involves the category contrasting against the situational background, thus considering its informational and communicative potential (James, 1990).

\section{English inversion types: their functional paradigm and connotation dimension}

There was a feeling of horror, a kind of bristling in the darkness, a sense of blood. They lay with their hearts in the grip of an intense anguish. The wind came through the tree fiercer and fiercer. All the cords of the great harp hummed, whistled, shrieked. And then came the horror of sudden silence, silence everywhere outside and downstairs. What was it? Was it a silence of blood? (Larence, 1995, 60) In the provided abstract the function of the inverted construction with an introductory there cannot be confined to an exclusively emphasis of the metaphorical phrases a feeling of horror and a sense of blood; it shapes emotive and imagery canvas of a certain part of the text. The expressive effect has as well been complemented by the imagery metaphorical construction with their hearts in the grip of an intense anguish, the cords of the great harp hummed, whistled, shrieked and the simple sentence with the repetition of the noun silence - And then came the horror of sudden silence, silence everywhere outside and downstairs. The rhetoric questions What was it? Was it a silence of blood? intensify the feeling of tension and the tragic character of the depicted situation. The lexeme horror ("a painful emotion compounded by loathing and fear, shuddering with terror and repugnance") (SOED, 1975, vol. 1: 836) and anguish ("mental suffering, pain and grief" (SOED, 1975, vol. 1: 71-72), thus actualizing the concepts 'FEAR' and 'ANGUISH' as those associated with hatred, an intense heart beating and apprehension (Stepanov, 2004: 894-896). 
She still dreamed of William, and of what he would do, with herself behind him. Never for a minute would she admit to herself how heavy and anxious her heart was because of him (Lawrence, 1995: 91). The second sentence in its subordinate clause contains the subject inversion she in its rhematic function, thus stressing its significance not only within the microcontext but also in a certain narration abstract. An adverbial phrase never for a minute functions as a discourse part theme complementing and expanding it. The proceeding complex structure she still dreamed of William, and of what he would do, with herself behind him with coordinate and subordinate link of its parts contributes to the text part semantic coherence. The inverted construction expressive potential extent has been remarkably intensified by morphological and lexical levels items. In particular, the modal verb would is aimed to convey the subject qualitative characteristics designating recurrence and attaching a certain categorical trait to the expressed action (Marokhovskiy, 1991: 92). The lexical level means such as an epithet phrase heavy and anxious [...] heart as well serves an additional detail in depicting the character's emotional state.

Shifting an adverbial semantic element to the initial position in sentences with the direct word order displays a fairly occurrence in English fiction texts:

They stood perched on the face of declivity, under the trees. "Well, I'll go again," he said. Away he went slipping, staggering, sliding to the next tree, into which he fell with a slam that nearly shook breath out of him. She came after cautiously, hanging on to the twigs and grasses (Lawrence, 1995: 309). Some linguists adhere to a view that shifting a verbal element to the initial position increases the text narration flow dynamic character (Marokhovskiy, 1991). The expressive colouring of the text is enhanced by the stylistically marked construction that nearly shook breath out of him functioning as one of the subordinate clauses in the complex syntactic structure.

V. Shevyakova claims that an inverted model with the introductory there is primarily aimed at the rheme emphasis. The latter is relevant in a number of cases: (1) close relation of an adverbial element (especially an extended one) with the corresponding item of the preceding sentence when these items should occupy contact positions; (2) syntactic subject close relations with the following sentence initial element; (3) the syntactic subject group has been extended with attributes, items of enumeration, etc. (Shevyakova, 1980: 127-128):

So there went on a battle between them. She knew she never fully had him. Some part, big and vital, in him, she had no hold over, nor did she ever try to get it, or even to realize what it was (Lawrence, 1995: 360-361). The use of inversion in one of the sentences of the provided context intends to draw a recipient's attention to the certain components. That's why it is presumed that the given syntactic model cannot be regarded as one totally devoid of emotive colouring. Stressed with the help of there construction the lexeme battle functions as the sentence rheme designating the concept 'CONFRONTATION' (SOED, 1975, vol. 2: 166). The following syntactic construction complements the discourse semantic structure attaching the dynamic character to the narration by depicting a moment of emotional tension experienced by one of the characters. The abstract emotive loading has been remarkably intensified by some additional means, in particular, an object component with the postpositional detached attributive element some part, big and vital to the sentence initial position as the theme of the complex structure part, and the use of the inverted construction nor did she ever try to get it with the negative particle nor and the auxiliary verb do in its emphatic function. An emphasis of the pronoun she functioning as the rheme assists to making this element a kind of the discourse part climax, thus helping to convey the personal qualities of characters. 


\section{Ukrainian inverted structures with movement and existential verbs as specific stylistic phenomenon}

The inversion of sentence predicates designating existence or movement displays a remarkable frequency in Ukrainian fiction texts. In the inverted structures the elements дужий, такий славний, - посміхнулась $i$ зітхнула Мирослава, $і$ зітхнули ї̈ вузькуваті usually follow the sentence subject: - Як добре, коли ти $\epsilon$, такий груди. ... - Ти чого занепокоївся? - здивувалась Мирослава. - Нічого, нічого, - тупо глянув на вікна, щзо деренчали від двигтіння машини. Зупиниться чи ні? Пішла далі. Що иее зі мною? Він далі схилився над Мирославою, зазирнув у ї̈ напівприплющзені очі. - Як добре, щзо ти є на світі. Найкрашца (Stelmakh, 1979: 203). The given syntactic model puts an emphasis on the predicate functioning as the rheme. In relation to dialogical speech abstracts, in particular, it gains a specific stylistic epic colouring (Bilodid, 1972: 427). In the analyzed abstract the inverted word order functions as a means of the characters' emotional state conveyance. The significance of these relations for each of them has been stressed by means of items representing different language levels. The writer resorts to usage of the postpositional adjectival attributes такий дужий, такий славний with the connotation enhancing the context expressiveness. The similar function is attached to the inner monologue rhetoric questions Зупиниться чи ні? Що ие зі мною? and a short answer to one of them Пішла далі which makes an impression of an intense situation. The repetition of the identical inverted structure Як добре, щзо ти є на світі and the nominal adjectival clause Найкращза with the contextual semantics corresponding to the detached attributes такий дужий, такий славний complement narration and to some extent neutralize tightness of the described circumstances.

The inverted structures containing an ontological component expressed by the lexeme $\epsilon c u$ gain a kind of pejorative connotation: I тоді лихі зморики розсікли чоло лісника, $a$ скособочений вид вичавив піт і злобу: - Дурна і нерозумна ти єси! Чого замість того, щьоб мати натуральні житейські радощі, сама над собою ставиш хрест? Для кого й для чого бережеш своє личко і все? I королеви так не берегли себе! (Stelmakh, 1979: 55). The lexeme $\epsilon c u$ is inherently expressive conveying irony and disdain. In the abstract cited this item and the inverted construction, in general, are aimed at reflecting the absolutely destructive emotional state of the character caused by a very negative and unpleasant reaction to him of a woman he was aiming to have relations with. The hopelessness has been stressed by different language items. The interrogative constructions and the final exclamatory sentence of the rhetoric character add up to the text semantics. The metaphoric constructions лихі зморики розсікли чоло, скособочений вид вичавив піт і злобу, мати натуральні житейські радощі, сама над собою ставиш хрест containing epithets лихі зморики, скособочений вид, натуральні житейські радощі as well the inherently and adherently expressive lexemes дурна (SUM, 1970-1980, vol. 2: 459) нерозумна (SUM, 1970-1980, vol. 5: 380) provide the characteristics of certain contextual elements and the general background of the situation.

In the inverted structures expressing movement the verbal element usually follows the group subject: У тебе, пане, нікого нема з чужих? - підозріло захрипів решітчастий, в нашорошених буркалах його стояло одне зловістя. - Нема. - Ну й мордоворот. Хоч би вночі не приснився! - А опріч тебе, хтось є в господі? - Стара людина. - Дивись мені. - перетрусив усім своїм дражливим решетом недовіру. - Коли щзо з чого -відразу обітнемо душу, тут їи і кінецьь. Мова мурмила обурила Магазаника: - Смерть у кожного за плечима ходить. - Перед очима теж! - бовкнув глекуватий недомірок. - Прошу, пане, 
веди в свій барліг (Stelmakh, 1979: 313). The text abstract cited reflects the emotional complexity of the war time atmosphere with its key features such as distrust, fear, mutual disdainful attitude towards each other. Such an atmosphere found its manifestation in characters' speech full of emotively marked items predominantly referring to syntactic and lexical language levels. The writer resorts to the frequent usage of the adherently expressive nominative and verbal sentences. The inverted sentence constitutes the so-called climax of the provided abstract constituting a metaphoric construction with an idiomatic figurative meaning Смерть у кожного за плечима ходить supplemented by a part of the nominative exclamatory phrase перед очима теж bearing the conceptual significance not only in the abstract but also in the whole text. The emotional strain of the depicted situation has been enhanced by the lexical items representing different parts of speech and functioning as means of the appearance description and general character evaluation, and consequently, forming a certain attitude to him. Totally pejorative connotations have been attached to metaphoric and epithet constructions formed by the lexical language elements: нашорошені буркала (еуеs), дражливе решето and глекуватий недомірок (indicating awkward body constitution), the idiomatic phrase обтинати душу (to kill (a person). Similar connotations are as well attached to inherently expressive substantive and verbal items bearing colloquial and derogatory style register - as бовкнути (бовкати (coll.) "говорити щось не подумавши, навмання, сказати те, що не слід" (SUM, 1970-1980, vol. 1: 206), мурмило (derog.) - "похмура замкнута людина, відлюдько" (SUM, 1970-1980, vol. 4: 829), барліг (derog.) - “неохайне брудне житло" (SUM, 1970-1980, vol. 1: 107), and the writer's individual lexical coinage мордоворот expressing highly negative and offensive estimation of the character.

\section{Conclusions}

Allomorphic inverted expressive models of the original fiction texts of the languages of distant genetic relationship enable to indicate and interpret a number of essential divergences in their expressive potential manifestation and realization. In English texts the syntactic models with the emphatic $d o$ and the introductory there are used for emphasizing semantically and conceptually significant elements. They attach the emotive colouring to a part of discourse. The narration stylistic features in English and Ukrainian are largely determined by the texts complementary means of the syntactic and lexical levels. An extent of emotiveness of the English inverted structures potential has been essentially increased due to their lower frequency and notable functional limitation. English inverted constructions constitute a kind of structural and connotative realia while in the Ukrainian language a variety of possible structural combinations diminishes their expressive value. Nevertheless, the Ukrainian sentences with existential and movement verbs display specificity in the English and Ukrainian binary contrasting. Items representing different language levels in the micro- and macrocontextual framework add up to the emotional perception of fiction.

\section{References}

Anishhenko L. P., Berezins'kiy V. P., Brovchenko T. O. (1981) Porivnyal'ni doslidzhennya z gramatiki angliys'koyi, rosiys'koyi ta ukrayins'koyi mov [Comparative study of English, Russian, and Ukrainian] Ed. by Ju. Zhluktenko. Kyiv: Nauk. dumka. [in Ukrainian]

Arakin V. D. (2005) Sravnitel'naya tipologiya angliyskogo i russkogo jazykov: [Contrastive Typology of English and Russian]. Moscow: FIZMATLIT. [in Russian] 
Arutjunova N. D. (1999) Jazyk i mir cheloveka [Human Language and World] Moscow: Jazyki russkoy kul'tury. [in Russian]

Fiala K. (1995) Sentence and discourse: An attempt at re-assessment of the background of utterances and sentences In. Proceedings of LP'94. Ed. by B. Palek. Prague: Charles University Press. P. 383-402.

Gal'perin I. R. (2006) Tekst kak ob\#ekt lingvisticheskogo issledovaniya [Text as an Object of Linguistic Research] Moscow: KomKniga. [in Russian]

James C. (1990) Contrastive Analysis. London \& New York: Longman.

Katuza I. (1975) English feature-grammar and its application to deviant sentences. Krakow: Pantswowe Widawnictwo Naukowe.

Kochetova V. (2014) Inversiya kak sredstvo intensifikatsii pragmaticheskogo aspekta vyskazyvaniya v sovremennom angliyskom yazyke [Inversion as a Statement Pragmatic Aspect Intensification Means] In Vestnik Moskovskogo gosudarstvennogo universityeta kultury I iskustv no. 6, pp. 244-247 [in Russian]

Obraztsova O. (2011) Linijna organizacija vislovljuvannja v anglijs 'kij, rosijs 'kiy ta ukraïns 'kij movah [Statement Linear Arrangenent in English, Russian and Ukrainian] Doctoral Thesis Review. Donets 'k. (in Ukrainian)

Pavlova A. (2009) Ponimaniye smysla predlozheniyv svyazi s mestom frazovogo udareniya pri vospriyatii pismennoi rechi [Meaning Understanding of the Written Speech in Relation to Phrasal Stress Position] in Voprosy psykholingvistiki. no. 9, pp. 70-90 [in Russian]

Shakhovskiiy V. (2008) Lingvisticheskaya teoriya jemotsiy [Linguistic Theory of Emotins] Moscow: Gnozis. [in Russian]

Shevyakova V. (1980) Sovremennyy anglijskiy yazyk. Poryadok slov. Aktual'noe chlenenie. Intonatsiya [Contemporary English Language: Word order, Actual Sentence Division, Intonation] Moscow: Nauka. [in Russian]

Stepanov Yu. (2004) Konstanty: Slovar'russkoy kul'tury. [Constants; Glossary of Russian Culture] Moscow: Akademicheskij proekt. [in Russian]

Morohovskiy A. N., Vorob'eva O P., Lihosherst N. I., Timoshenko Z. V. (1991) Stilistika angliyskogo yazyka [English Stylistics]. Kyiv: Vyshha shkola. [in Russian]

(Bilodid) Suchasna ukraïns 'ka literaturna mova. Stylistyka (1972) [Contemporary Ukrainian Language Stylistics] (I. Bilodid, Ed.) Kyiv: Nauk. dumka. [in Ukrainian]

Croft W. (1993) Typology and Universals. Cambridge: Cambridge University Press.

Yartseva V. (1981) Kontrastivnaya gramatika [Contrastive Grammar] Leningrad: Nauka.

(SUM) Slovnyk ukrayins 'koyi movy (1970 -1980) [Dictionary of Ukrainian Language] Ed. By I. Bilodid Kyiv: Nauk. dumka. V. 1-11.

(SOED) The Shorter Oxford English Dictionary on Historical Principles. / Rev. and Ed. C. T. Onions. New York: Oxford University Press, 1975. V. 1-2.

Stel'mah, M. (1979) Chotyry brody [Four Fords] Kyiv: Rad. pis'mennik. [in Ukrainian] Lawrence, D. H. (1995) Sons and Lovers London \& New York: Penguin Books. 